\title{
Performance of Portable Battery Charger of Monocrystalline Solar Panel
}

\author{
Fitria Hidayanti \\ Engineering Physics Department, Universitas Nasional, Jakarta 12520 Indonesia \\ fitriahidayanti@gmail.com
}

\begin{abstract}
The direct current voltage stabilizer generated by solar cells is required to set the output voltage of the charger to be stable and constant. To stabilize the direct current voltage fluctuations generated by solar cells can be done by installing an integrated circuit regulator that produce a certain and constant output voltage according to he needs. The average of current and voltage are generated for data 1 , current $21.8 \mathrm{~mA}$ and voltage $5.07 \mathrm{~V}$, data 2 , current $11.9 \mathrm{~mA}$ and voltage $5.0 \mathrm{~V}$ and data 3, current $26.4 \mathrm{~mA}$ and voltage $5.09 \mathrm{~V}$. Battery charging time from empty to full condition for data 1 is 74 hours, data 2 is 135 hours and data 3 is 61 hours.
\end{abstract}

Key words : Portable, Monocrystalline, Battery Charger, Performance, Solar Panel

\section{INTRODUCTION}

Electricity supply in remote areas in Indonesia is very lacking while student lighting needs to study at night is a very important necessity $[1,2]$. Lack of electricity supply causes uncertainty for students in learning especially at night. This has an impact on the decline in learning interest in students. Nowadays, the conversion of energy to source electrical energy from various sources is a research concern [3-6].

In the utilization of solar energy, the device needed is solar cells. In a series of solar panel required a portable battery charger. Some research related to portable battery charger such as Varadajaran [7] explained about the portable charger that applied on some brands of mobile phones. Meanwhile, Tavora [8] explained the use of Maximum Power Point Tracking technology on battery charging of portable electronic devices. Another researcher, Syed [9] explained about the manufacture of portable chargers mounted on a jacket. Based on the research, need another innovation in the utilization of solar panels that are applied to a portable battery charger with direct charge system or with stored in the battery first.

\section{Voltage Stabilizer}

Stabilizer [10] is an electrical appliance that works stabilizes an input so that a fixed and constant output is obtained. The direct current voltage stabiliser generated by solar cells is required to set the output voltage of the charger to be stable and constant. To stabilize the direct current voltage fluctuations generated by solar cells can be done by installing an Integrated Circuit (IC) regulator that will produce a specific and constant output voltage according to the needs. The IC regulator is installed after the solar cell circuit and before entering the amplifier circuit. Installation of the IC regulator shown in Figure 1.

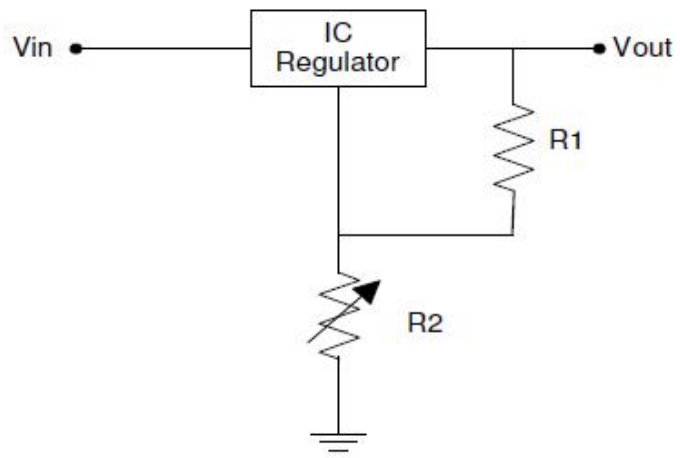

Figure 1: Installation of IC Regulator [11]

The voltage output $\left(\mathrm{V}_{\text {out }}\right)$ can be adjusted by setting the $\mathrm{R} 2$ barrier. Equation 1 of the series is as follows.

$$
V_{\text {out }}=\frac{R_{2}+R_{2}}{R_{1}}(1.25 \mathrm{~V})
$$

Value $1.25 \mathrm{~V}$ is the reference voltage $\left(\mathrm{V}_{\mathrm{REF}}\right)$ IC LM317.

\section{Current Amplifier}

To get a larger current can use a transistor mounted with a common series of emitter attached to the series with a load or called a series organizer. Installation of the transistor can be seen in Figure 2. The priority in the serial manager is the magnitude of the power dissipation in the amplifier transistor as equation 2 .

$$
P_{0}=V_{C E}, I_{C}
$$

where,

$$
\begin{aligned}
& \mathrm{V}_{\mathrm{CE}}=\text { Voltage of collector-emitter, } \mathrm{V}_{\text {in }}-\mathrm{V}_{\text {out }} \\
& \mathrm{I}_{\mathrm{C}} \quad=\text { Load current plus current divider }
\end{aligned}
$$




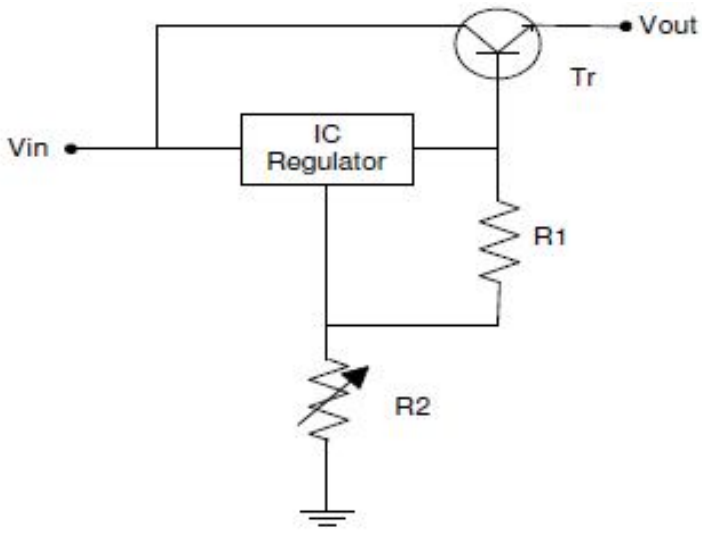

Figure 2: Installation of amplifier transistors [11]

Electrical energy was very important for our life [12-15]. Nevertheless, the use of electricity in Indonesia is not evenly distributed, especially in remote and rural areas so that solar cell device such as monocrystalline $[16,17]$ are needed to help the student to get lighting for study at night.

Solar panels are capable of generating electricity using photovoltaic effects [18-21] Two semiconductor layers combined to produce this photovoltaic effect. When exposed to sunlight, the coating of the material absorbs photons resulting in the excitation of electrons. This excitation causes the electrons to move from layer one to the other to produce an electric current.

\section{MATERIALS AND METHODS}

The design scheme is shown in Figure 3. The research methods (Figure 4) are described in the following flowcharts.

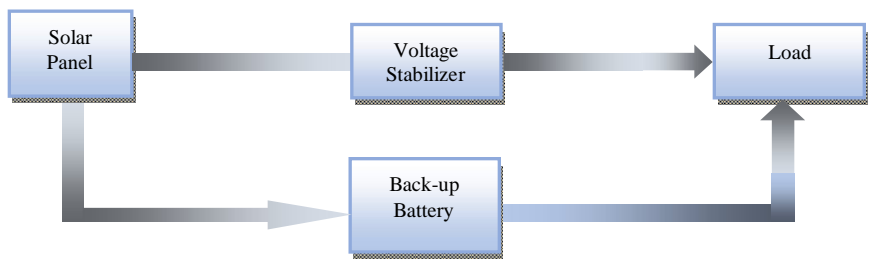

Figure 3: Portable Battery Charger Design Scheme

Data collection was carried out at 9 a.m. - 4 p.m. The solar energy that absorbed by solar cells has maximum intensity. The data taken was the data voltage, current, solar radiation and temperature. Testing results of solar cell performance which involve in the form of graphs showing the relationship between current, voltage from solar panels and batteries and charging time.

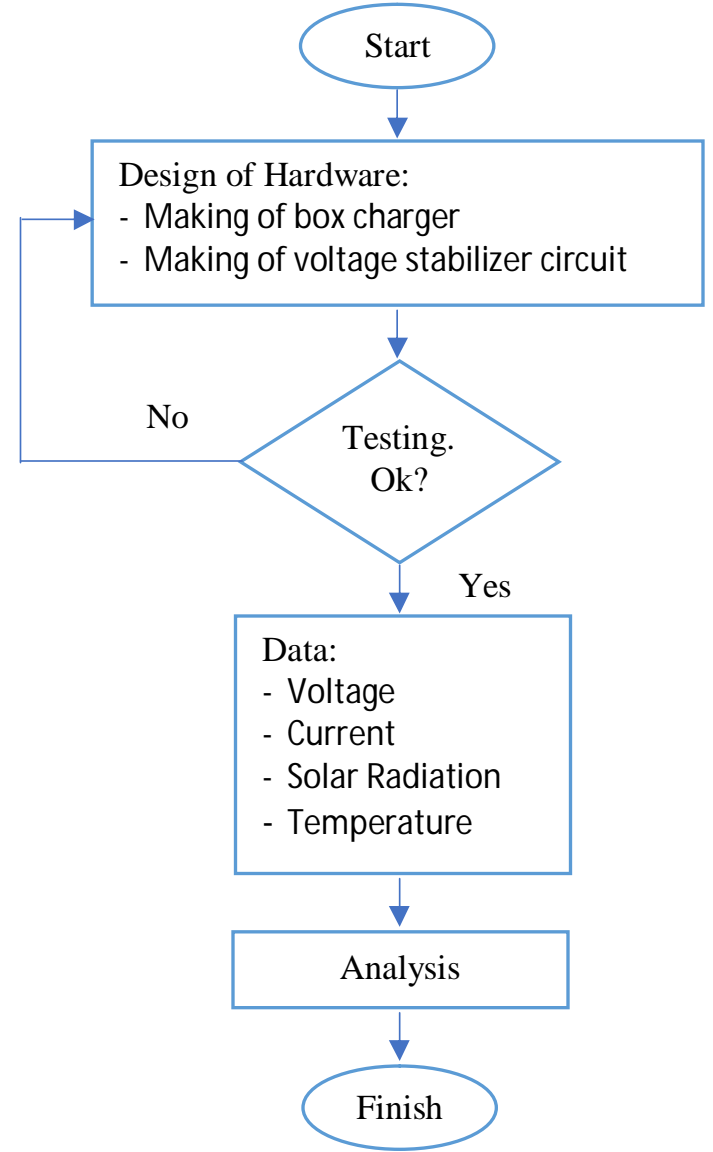

Figure 4: Research Flowchart

\section{RESULTS AND DISCUSSION}

Testing was conducted starting at 9 a.m. - 4 p.m. using monocrystaline solar panels. The position of the solar panel is facing upwards with an altitude of $1.5 \mathrm{~m}$ from the ground. The specifications of solar panels used as follow.

- Type : Monocrystaline Silicon

- Power : $1.25 \mathrm{~W}$

- Voltage $: 5 \mathrm{~V}$

- Current : $250 \mathrm{~mA}$

- Size : 110 x $70 \mathrm{~mm}$

As a load used mobile phone with a voltage battery specifications 3.7 VDC and capacity $1350 \mathrm{mAh}$.

As a description of the conditions when testing can be seen on Figure 5 and Figure 6. Figure 5 shows the relationship of solar radiation to time. Based on the graph obtained the average solar radiation on data 1 is $89.5 \mathrm{~W} / \mathrm{m}^{2}$, data 2 is $50.1 \mathrm{~W} / \mathrm{m}^{2}$, and data 3 is $139.7 \mathrm{~W} / \mathrm{m}^{2}$. In three data there is the highest 
value solar radiation that is $711.8 \mathrm{~W} / \mathrm{m}^{2}$. The average temperature of data 1 is $33.1{ }^{\circ} \mathrm{C}$, data 2 is $32.2{ }^{\circ} \mathrm{C}$ and data 3 is $33.2^{\circ} \mathrm{C}$.

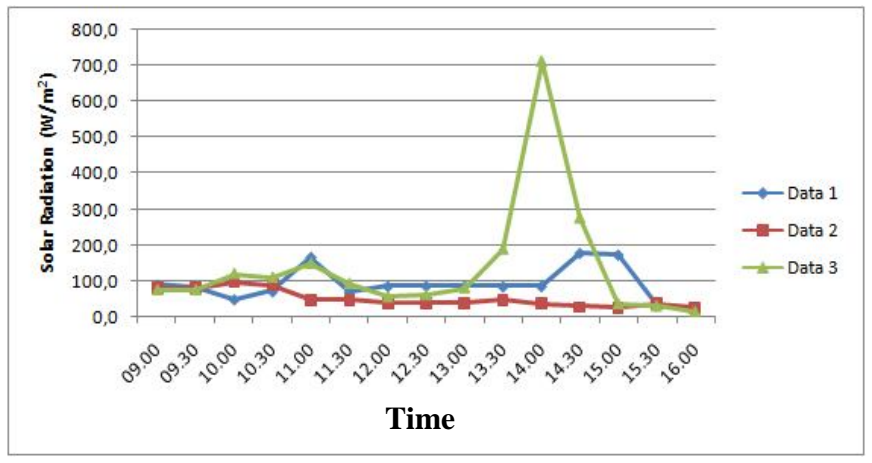

Figure 5: Effect of Solar Radiation on Time

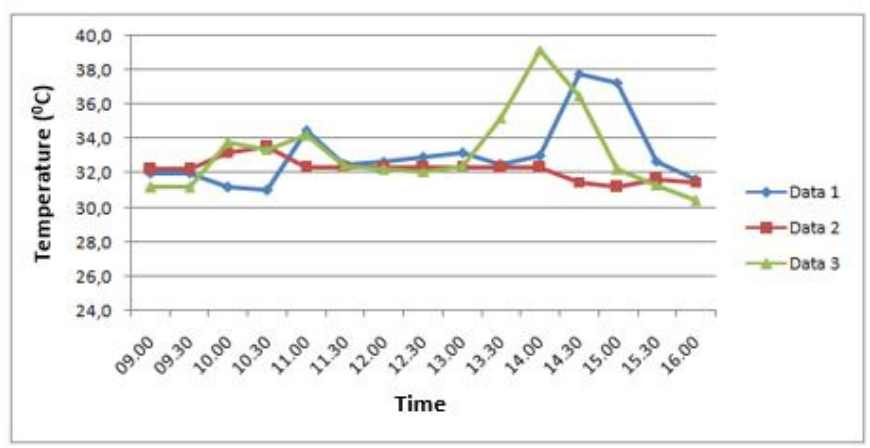

Figure 6: Effect of Temperature on Time

\section{Testing of Current and Voltage Solar Panel}

Figure 7 shows the voltage connection to time. The maximum voltage of data 1 is $5.26 \mathrm{~V}$, data 2 is $5.08 \mathrm{~V}$ and Data 3 is 5.29 $\mathrm{V}$. While the average voltage for data 1 is $5.07 \mathrm{~V}$, data 2 is 5.0 $\mathrm{V}$ and Data 3 is $5.09 \mathrm{~V}$. The maximum voltage should be obtained at 11 a.m. until 1 p.m. because of the sun's position perpendicular to the solar panels. But the condition is not achieved because when retrieving weather data changes.

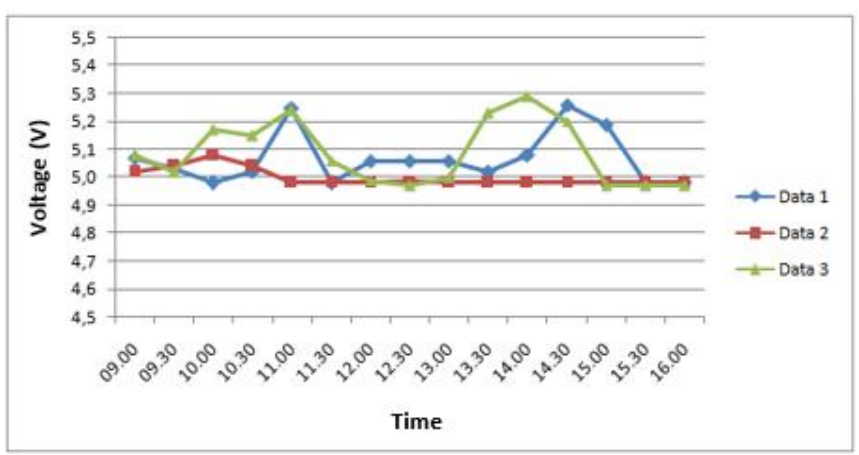

Figure 7: Effect of Voltage on Time

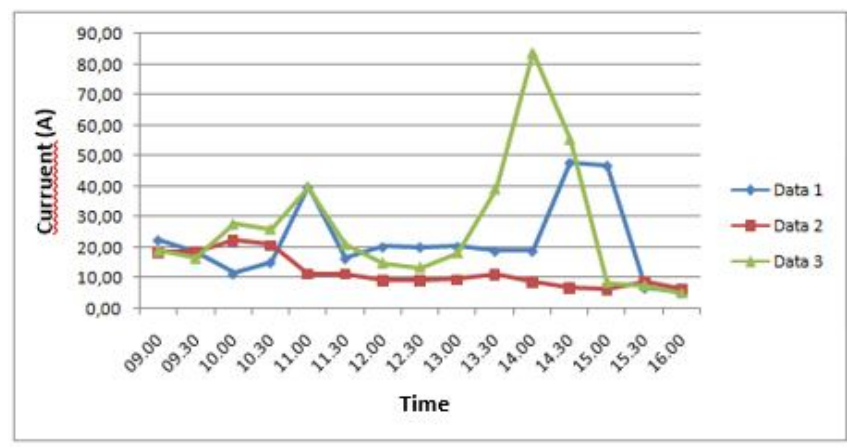

Figure 8: Effect of Current on Time

Figure 8 shows the current relationship of solar panels against time where the current average of data 1 is $21.8 \mathrm{~mA}$, data 2 is $11.9 \mathrm{~mA}$ and data 3 is $26.4 \mathrm{~mA}$. To determine the length of battery charging time can be used following equation 3 .

$$
\text { Charging time }(h)=\frac{\text { Bathery capacity }(A h)}{\text { Charging current }(A)} \times 1.2
$$

\section{CONCLUSION}

In summary, this research design of portable battery charger has been done and the system created can function. The current average and voltage are generated for data 1 , current as $21.8 \mathrm{~mA}$ and voltage $5.07 \mathrm{~V}$, data 2, current as $11.9 \mathrm{~mA}$ and voltage $5.0 \mathrm{~V}$ and data 3 , current as $26.4 \mathrm{~mA}$ and voltage 5.09 $\mathrm{V}$. The battery charge time from the empty condition until fully charged for data 1 is 74 hours, data 2 is 136 hours and data 3 is 61 hours.

\section{ACKNOWLEDGEMENT}

Thank you for Lembaga Penelitian dan Pengabdian kepada Masyarakat (LPPM) Universitas Nasioal and my colleagues at Faculty of Engineering and Science, Universitas Nasional, Jakarta, Indonesia.

\section{REFERENCES}

1. Blum, N. U., Wakeling, R. S., \& Schmidt, T. S. Rural electrification through village grids-Assessing the cost competitiveness of isolated renewable energy technologies in Indonesia. Renewable and Sustainable Energy Reviews, 22, 482-496. 2013. https://doi.org/10.1016/j.rser.2013.01.049

2. Derks, M., \& Romijn, H. Sustainable performance challenges of rural microgrids: Analysis of incentives and policy framework in Indonesia. Energy for Sustainable Development, 53, 57-70. 2019. https://doi.org/10.1016/j.esd.2019.08.003

3. Hidayanti F., Wati E.K., and Miftahudin M. F. Design of Energy Harvesters on Motorcycle Exhaust using 
Thermoelectric Generator for Power Supply Electronic Device. International Journal of Renewable Energy Research. 10(1), 251 - 259. 2020.

4. Hidayanti F., Wati E.K., and Akbar H. Energy Harvesting System Design for Converting Noise into Electrical Energy. International Journal of Advanced Science and Technology. 29(03), 4791 - 4802. 2020.

5. Hidayanti F., Rahmah F., and Wiryawan A. Design of Motorcycle Security System with Fingerprint Sensor using Arduino Uno Microcontroller. International Journal of Advanced Science and Technology. 29(05), 4374 - 4391.2020.

6. Hidayanti F., Santoso H. H., and Amalia D. Induction Measurement of Extra High Voltage Air Duct. International Journal of Emerging Trends in Engineering Research. 8(4), 1424 - 1427. 2020. https://doi.org/10.30534/ijeter/2020/78842020

7. Varadarajan, M. Coin based universal mobile battery charger. IOSR Journal of Engineering. Vol.2. no.6. pp.1433-1438. 2012.

8. Távora, F., \& Maia, A. S. Solar Battery charger for portable devices application. SiliconReef. Brazil. 2012.

9. Syed, U., \& Memon, A. Design and Manufacturing of Solar Jacket for Charging the Mobile and Laptop Devices. International Journal of Current Engineering and Technology, 2(4), 365-368. 2012.

10. Jerez, J. G. U.S. Patent Application No. 15/569,396. 2019.

11. Maki, S., Takano, Y., \& Yokoyama, K. U.S. Patent No. 10,466,728. Washington, DC: U.S. Patent and Trademark Office. 2019.

12. Hidayanti F., Rahmah F., and Sahro A. Mockup as Internet of Things Application for Hydroponics Plant Monitoring System. International Journal of Advanced Science and Technology. 29(05), 5157 - 5164. 2020.

13. Hidayanti F., Rahmah F., and Septratama S. Design of Single-Axis Solar Tracker based on Arduino Uno Microcontroller. International Journal of Emerging Trends in Engineering Research. 8(4), 983 - 986. 2020. https://doi.org/10.30534/ijeter/2020/07842020

14. Hidayanti F., Extraction of Limonite Nickel Ore of Tanjung Buli, Halmahera by Coal Roasting and Acid Leaching. International Journal of Mechanical and Production Engineering Research and Development. 10(2), 513 - 522. 2020.

15. Hidayanti F., Development of Mercury Film Electrode for Cadmium Ion Determination using Voltammetry. International Journal of Advanced Science and Technology. 29(03), 5156 - 5163. 2020.

16. Bahabry, R.R., et al., Solar Cells: Corrugation Architecture Enabled Ultraflexible Wafer $\square$ Scale High $\square$ Efficiency Monocrystalline Silicon Solar Cell (Adv. Energy Mater. 12/2018). Advanced Energy Materials, 8(12). p. 1870055. 2018.

17. Hashmi, G., et al., Study of the enhancement of the efficiency of the monocrystalline silicon solar cell by optimizing effective parameters using PC1D simulation. Silicon, p. 1-8. 2018. https://doi.org/10.1007/s12633-017-9649-3

18. Fthenakis, V.M. and P.A. Lynn, Electricity from Sunlight. Photovoltaic-systems Integration and Sustainability. John Wiley \& Sons. 2018.

19. Hidayanti F., Rahmah F., and Agusto J. Design of Solar Tracker on Solar Panel with Fresnel Concentrator. International Journal of Advanced Science and Technology. 29(05), 1014 - 1025. 2020.

20. Hidayanti F., Rahmah F., and Ikrimah M. Dual-Axis Solar Tracking System Efficiency for Hydroponics Pump. International Journal of Emerging Trends in Engineering Research. 8(6), 2631 - 2634. 2020. https://doi.org/10.30534/ijeter/2020/67862020

21. Hidayanti F., Lestari K.R., and Anwar R. Arduino Based Conductive Silver Lamination Device. International Journal of Emerging Trends in Engineering Research. 8(2), 265 - 270. 2020. https://doi.org/10.30534/ijeter/2020/04822020 